\title{
POTENSI LIMBAH BAHAN BERBAHAYA DAN BERACUN (B3) DI WILAYAH DKI JAKARTA dan STRATEGI PENGELOLAANNYA
}

\author{
Studi Potensi Limbah B3 di Wilayah DKI Jakarta Tahun 2004
}

Oleh : Setiyono

\author{
Kelompok Teknologi Pengelolaan Air Bersih dan Limbah Cair \\ Pusat Pengkajian dan Penerapan Teknologi Lingkungan - BPPT
}

\begin{abstract}
Limbah B3 dapat menimbulkan dampak negative yang sangat besar dan bersifat akumulatif, sehingga kadarnya makin lama akan makin meningkat. Wilayah DKI Jakarta yang padat dengan berbagai kegiatan menghasilkan berbagai jenis limbah yang sebagian bersifat berbahaya dan beracun, yang biasa disebut dengan limbah B3.

Banyak pihak yang tidak menyadari bahwa limbah yang dihasilkannya sebagian merupakan limbah B3 sehingga penanganan limbah B3 hanya dipusatkan pada sektor industri dan rumah sakit saja. Hal ini menyebabkan limbah B3 dari sektor domestik (terutama rumah tangga) terlupakan. Mengingat besarnya resiko yang dapat ditimbulkan dan kondisi yang demikian maka perlu disusun suatu strategi dan prioritas dalam pengelolaan limbah B3 dari semua sumber yang ada.
\end{abstract}

Keywords: Hazardous waste.

\section{PENDAHULUAN}

\subsection{Latar Belakang}

Limbah bahan berbahaya dan beracun (B3) yang dibuang langsung ke lingkungan dapat menimbulkan dampak negative yang sangat besar dan bersifat akumulatif, sehingga kadarnya makin lama akan makin meningkat. Karena sifat persistant dari bahan B3, maka dampak yang timbul dapat berantai mengikuti proses pengangkutan (sirkulasi) bahan dan jaring-jaring rantai makanan. Mengingat besarnya resiko yang ditimbulkan oleh limbah B3, maka pemerintah berusaha untuk mengelola limbah B3 secara menyeluruh, terpadu dan berkelanjutan. Pengelolaan ini bertujuan untuk mencegah dan menanggulangi pencemaran dan/atau kerusakan lingkungan hidup yang diakibatkan oleh limbah B3 serta melakukan pemulihan kualitas lingkungan yang sudah tercemar sehingga sesuai fungsinya kembali.

Untuk melakukan pengelolaan limbah B3, diperlukan suatu data potensi yang memuat timbulan limbah tersebut, jenis dan sifatnya serta penyebarannya di wilayah. Dengan tersedianya data ini diharapkan, pengelolaan yang dilakukan dapat tepat sasaran sehingga hasilnya dapat maksimal.

\subsection{Permasalahan}

Wilayah DKI Jakarta padat dengan berbagai kegiatan, baik pemukiman, perdagangan maupun industri. Semua kegiatan tersebut menghasilkan limbah cair maupun padat. Sebagian dari limbah itu bersifat berbahaya dan beracun, yang biasa disebut dengan limbah B3.

Banyak pihak yang tidak menyadari, bahwa limbah B3 tidak hanya dihasilkan oleh industri saja, tetapi dari sektor pemukiman dan perdagangan juga menghasilkan limbah B3. Sampai saat ini industri dan rumah sakit dituding sebagai pihak yang menghasilkan limbah B3, sehingga perhatian dan penanganan limbah B3 hanya dipusatkan di kedua sektor tersebut. Kondisi ini menyebabkan limbah B3 dari sektor domestik (terutama rumah tangga) terlupakan.

Melihat permasalahan di atas perlu adanya suatu kajian dan penelitian yang dapat menunjukkan potensi dan penyebaran limbah B3 di semua sektor kegiatan (industri, rumah sakit dan rumah tangga).

\section{TINJAUAN PUSTAKA}

\subsection{Difinisi Limbah B3. ${ }^{2)}$}

Limbah bahan berbahya dan beracun, disingkat limbah B3, adalah sisa suatu usaha 
dan/atau kegiatan yang mengandung bahan berbahaya dan/atau beracun yang karena sifat dan/atau konsentrasinya dan/atau jumlahnya, baik secara langsung maupun tidak langsung, dapat mencemarkan dan/atau merusakkan lingkungan hidup, dan/atau dapat membahayakan lingkungan hidup, kesehatan, kelangsungan hidup manusia serta makhluk hidup lain. (PP. No. 18 th. 1999 tentang "Pengelolaan Limbah Bahan Berbahaya dan Beracun").

\subsection{Pengelolaan Limbah B3}

Mengingat besarnya resiko yang dapat ditimbulkan, maka perlu diupayakan suatu kegiatan pengelolaan bahan/limbah B3 yang terpadu dan bekesimambungan dimana unsur manajemen akan memegang peranan yang sangat penting dalam sistem pengelolaan yang dimaksud. Pengelolaan bahan/limbah B3 harus dimulai sejak masih dalam bentuk bahan baku, selama proses produksi, proses terbentuknya limbah sampai pengolahan limbah dan penimbunan akhir dari sisa hasil pengolahan limbah B3. Dengan sistem pengelolaan seperti itu, maka semua pihak yang berhubungan dengan bahan/limbah B3 (produsen, pemanfaat, pengumpul, pengangkut, pengolah, penimbun) merupakan satu kesatuan yang tidak dapat untuk dipisahkan dan setiap ada pemindah tanganan atau pemindahan lokasi limbah antar pihak atau lokasi harus disertai dengan dokumen limbah B3 yang diberikan pada waktu penyerahan limbah.

Diagram alir sistem pengelolaan limbah B3 secara menyeluruh sesuai dengan peraturan perundang-undangan yang berlaku seperti tersebut di atas dapat dilihat pada Gambar 1.

\subsection{Pengelolaan Limbah B3 Secara Terpadu}

Pengelolaan limbah B3 secara terpadu dan menyeluruh harus dilaksanakan bersamasama antara Bapedal, Pemda dan Badan Usaha yang dapat diwujudkan dalam suatu "Program Kemitraan Dalam Pengelolaan Limbah B3" yang selanjutnya disingkat dengan program KENDALI B3. Tujuan dari program KENDALI B3 adalah :

a. Terkendalinya pencemaran lingkungan;

b. Terkendalinya pembuangan limbah B3 ke lingkungan tanpa pengolahan;

c. Mendorong pelaksanaan upaya minimalisasi limbah B3 melalui kegiatan pengurangan limbah pada sumbernya, penggunaan kembali, daur ulang dan pemanfaatan kembali;

d. Tercapainya kualitas lingkungan yang baik; e. Ditaatinya ketentuan-ketentuan pengelolaan limbah B3.

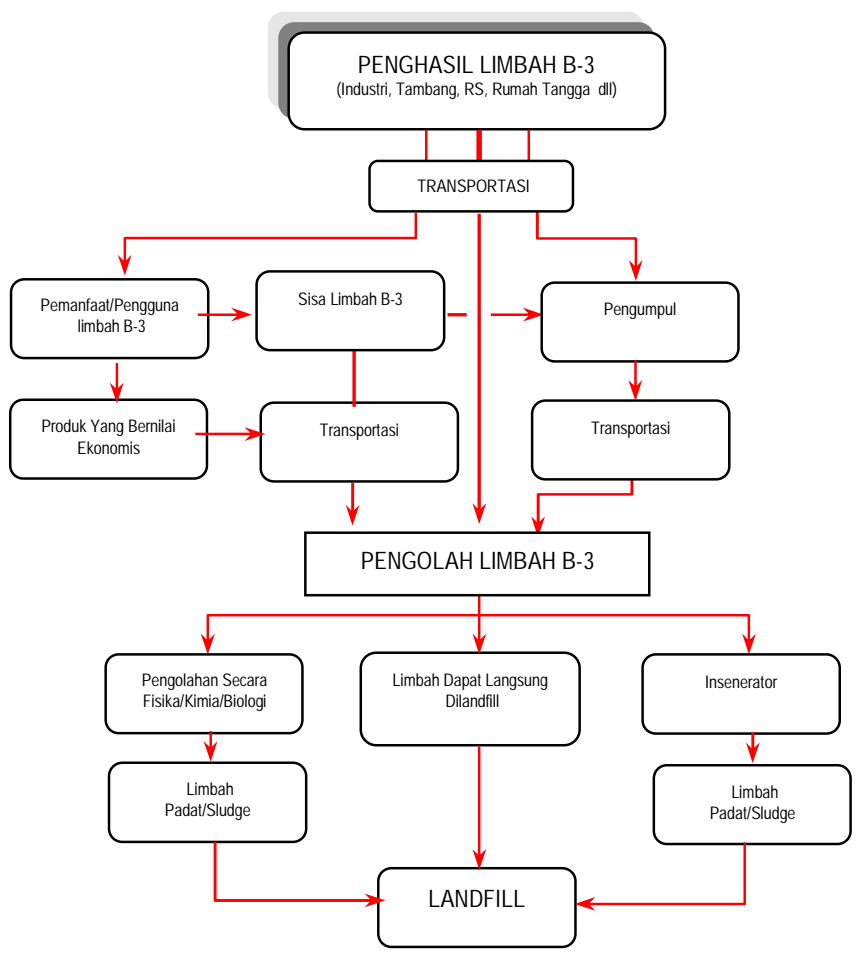

Gambar 1 : Diagram Alir Sistem Pengelolaan Limbah B3.

Sedangkan sasaran dari program KENDALI B3 adalah:

a. Terciptanya sistem pengelolaan limbah B3 yang berdaya guna dan berhasil guna;

b. Meningkatkan kemampuan aparat pemerintah baik di daerah maupun pusat dalam pengawasan pengelolaan limbah B3.

Ada tiga kelompok dalam pelaksanaan program KENDALI B3, yaitu Pemda, Bapedal dan Badan Usaha. Badan Usaha mana yang harus/wajib ikut dalam program ini harus mempunyai kriteria yang jelas atau dalam proses penentuannya jelas. Beberapa langkah yang dapat diambil untuk menetapkan Badan Usaha mana yang wajib ikut dalam program KENDALI B3, yaitu:

a. Identifikasi,

Yaitu identifikasi Badan Usaha yang berpotensi menghasilkan limbah B3,

b. Daftar Pertanyaan,

Kepada Badan Usaha yang berpotensi menghasilkan limbah B3 dikirimkan daftar pertanyaan tentang pengelolaan limbah B3 oleh Bapedalwil atau Pemda.

c. Peninjauan Lapangan,

Untuk memastikan kondisi pengelolaan limbah B3, maka dilakukan kunjungan 
pemantauan awal oleh Bapedal bersama dengan Pemerintah Daerah.

d. Penetapan,

Dari evaluasi daftar pertanyaan dan hasil kunjungan ditetapkan Badan Usaha prioritas sebagai peserta program KENDALI B3 oleh Bapedal berdasarkan identifikasi yang dilakukan oleh Pemerintah Daerah.

Setelah suatu Badan Usaha ditetapkan sebagai peserta program KENDALI B3, maka perlu dibuat suatu kesepakatan bersama untuk melakukan pengelolaan limbah B3 yang ada. Untuk lebih jelasnya penentuan badan usaha yang wajib ikut dalam program KENDALI B3 dapat dilihat pada skema Gambar 2.

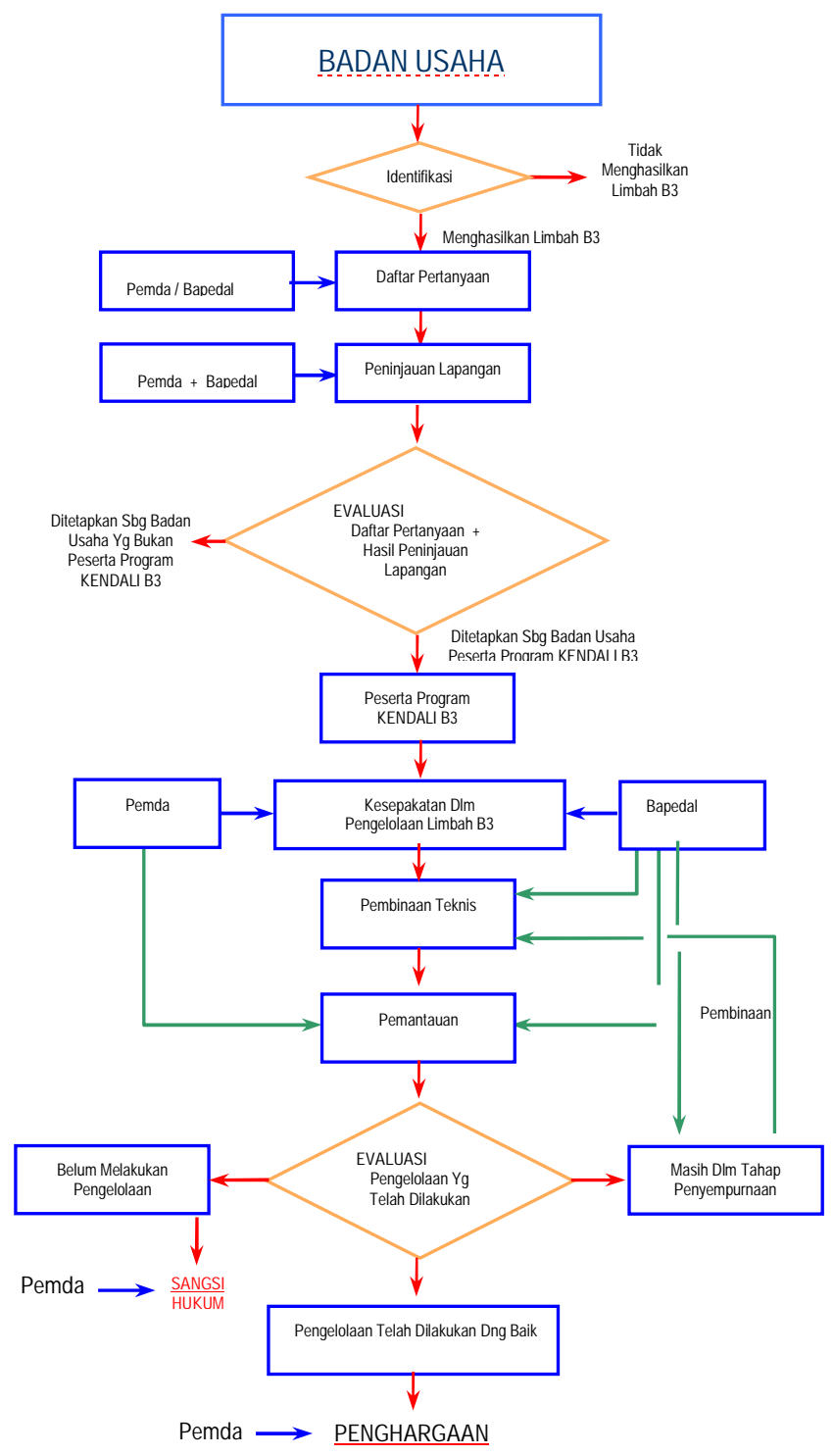

Gambar 2: Skema Penetapan Badan Usaha Yang Wajib Ikut Dalam Program KENDALI B3.

\subsection{Pengelolaan Limbah B3 Oleh Pemerintah}

Sampai saat ini sektor industri merupakan salah satu penyumbang bahan pencemar yang terbesar di kota-kota yang mengandalkan kegiatan perekonomiannya dari industri. Untuk menghindari terjadinya pencemaran yang ditimbulkan dari sektor industri, maka diperlukan suatu sistem yang baik untuk melakukan pengawasan dan pengelolaan limbah industri, terutama limbah B3-nya. Pelaksanaan pengelolaan limbah B3 dilakukan oleh Pemerintah Daerah dengan berdasarkan ketentuan-ketentuan yang berlaku sesuai Peraturan Pemerintah dan Keputusan Kepala Bapedal yang mengatur tentang pengelolaan limbah B3.

\section{POTENSI PENGHASIL LIMBAH B3}

\subsection{Sumber Limbah B3.}

Limbah B3 dihasilkan dari berbagai sumber antara lain, industri, rumah tangga, rumah sakit, pertambangan, pertanian dan perkebunan, transportasi dll. Sampai saat ini penghasil limbah B3 terbesar masih berasal dari sektor industri. Meski demikian kita tidak boleh mengbaikan limbah B3 yang berasal dari sektor lain yang jumlahnya relatif kecil, karena dampak yang ditimbulkan oleh limbah ini dapat menyebar ke area yang sangat luas dan dalam konsentrasi yang kecil saja dapat menimbulkan dampak yang besar. Hal lain yang sangat perlu diantisipasi adalah adanya berbagai pihak penghasil limbah B3 tetapi mereka tidak menyadari limah yang dihasilkan merupakan bahan yang berbahaya dan atau pihak penghasil yang tidak mengetahui sama sekali apa yang dihasilkannya dapat menimbulkan bahaya yang besar.

Ada sepuluh jenis kegiatan yang menghasilkan limbah B3 di wilayah DKI Jakarta yang sampai saat ini belum mampu mengelola limbah B3-nya sesuai dengan persyaratan pengelolaan limbah B3 yang berlaku. Ke sepuluh sumber tersebut yaitu: percetakan, bengkelbengkel, cuci cetak film, pengumpul minyak pelumas bekas, penyamakan kulit, rumah sakit tipe C dan D, laboratorium, pengelolaan pestisida kadaluarsa, binatu (Laundry \& Dry Cleaning) dan rumah tangga. Ketidak mampuan mereka meliputi bidang finansial, SDM, teknologi dan sarana dan prasarana yang ada. Meskipun demikian, upaya pengelolaan dari ke sepuluh sumber tersebut harus tetap dilakukan untuk mencegah hal-hal yang tidak diinginkan. 


\subsection{Limbah B3 dari sektor industri}

Sektor industri merupakan sumber limbah B3 terbesar, tetapi timbulan limbah yang berasal dari sektor ini relatif lebih mudah untuk dimonitor. Di wilayah DKI Jakarta juga terdapat berbagai industri, yang disinyalir sebagian dari mereka menghasilkan limbah B3. Sampai saat ini data detail berapa jumlah limbah B3 yang dihasilkan dan berapa yang sudah dikelola dengan benar dari sektor ini belum ada. Namun data jumlah industri yang ada di wilayah DKI telah dapat dilihat seperti pada Lampiran Tabel 1.

Dari tabel tersebut terlihat ada berbagai industri yang berpotensi menghasilkan limbah B3, seperti industri tekstil, kulit, furnitur, kertas, percetakan, penerbit, reproduksi media rekaman, kimia dan barang-barang dari bahan kimia, logam dasar, barang dari logam, mesin dan peralatannya, daur ulang barang logam dan industri pengolahan.

Berikut disajikan berbagai foto kegiatan yang berhubungan dengan industri kecil dan banyak menghasilkan limbah B3 yang masih belum terkelola dengan baik.

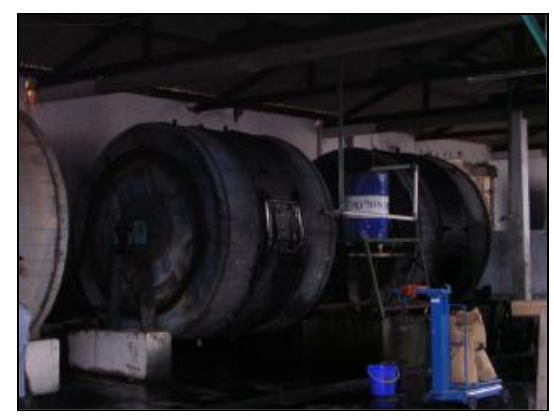

Foto 1 : Tanin (Rotary Drum) Reaktor Penyamakan Kulit (sumber limbah B3)

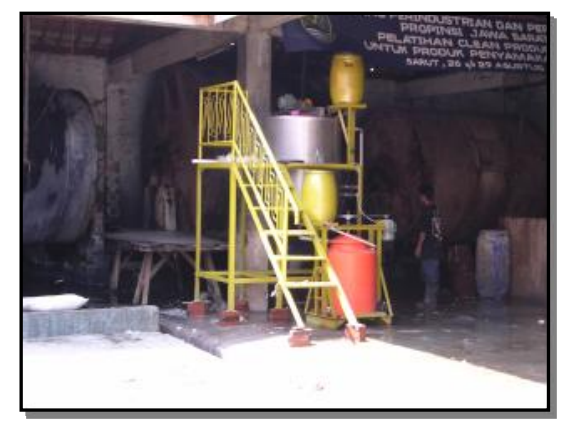

Foto 2 : Peralatan Recovery Crom dari limbah industri penyamakan kulit

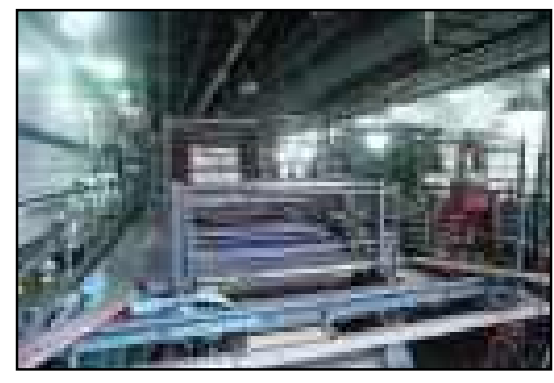

Foto 3 : Kegiatan percetakan .

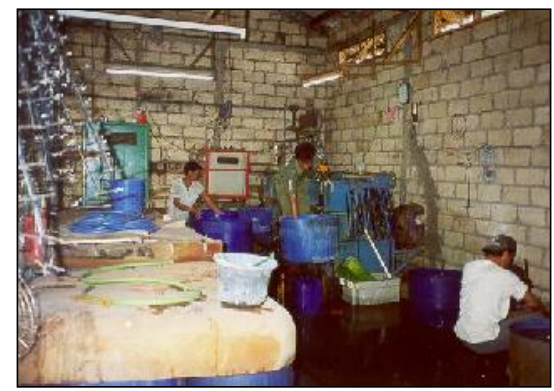

Foto 4 : Industri kecil elektro plating.

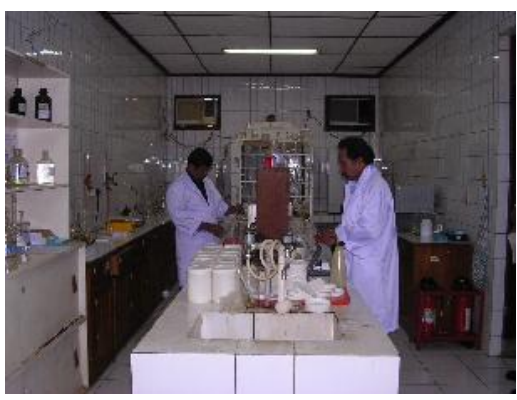

Foto 5 : Laboratorium.

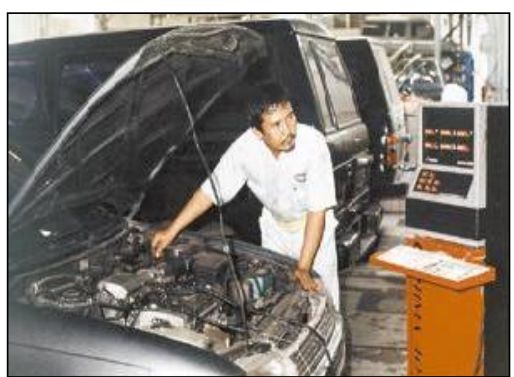

Foto 6 : Kegiatan bengkel.

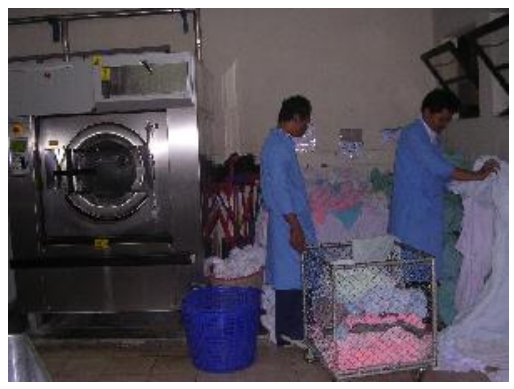

Foto 7 : Binatu /loundry. 


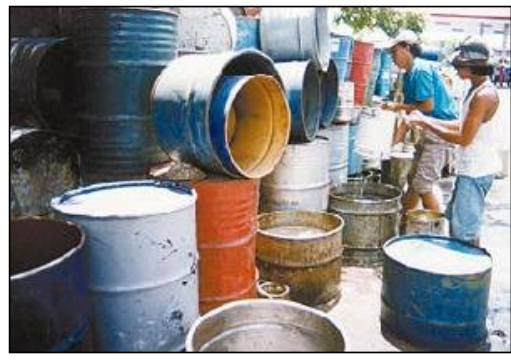

Foto 8 : Barang bekas terkontaminasi B3.

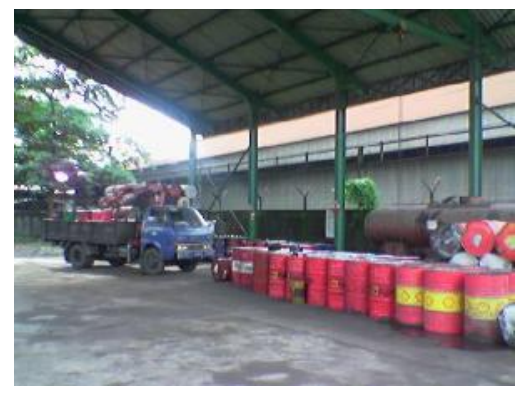

Foto 9 : Pengumpulan oli bekas.

\subsection{Limbah B3 dari sektor rumah tangga}

Limbah B3 juga dihasilkan dari kegiatan rumah tangga meski dalam jumlah yang relatif kecil dan dalam waktu yang tidak pasti, sehingga keberadaannya terkadang kurang mendapatkan perhatian. Gawatnya lagi, beberapa produk juga berbahaya saat digunakan, seperti kamper dan pengharum ruangan. Untuk mencegah hal-hal yang tidak diinginkan, maka limbah B3 dari rumah tangga harus segera diwaspadai keberadaannya, karena meski jumlahnya sangat sedikit dampak yang dapat ditimbulkan dapat berantai dan dalam jangka waktu yang lama.

Limbah B3 rumah tangga memang sedikit, tidak sampai $2 \%$ dari timbulan sampah domestik, tetapi termasuk kecil-kecil cabe rawit. Menurut US-AEP (United States Agency for Enviroment Protection) sebuah baterai bermerkuri didalam enam ton sampah, sudah melebihi ambang batas merkuri yang diijinkan dalam limbah padat, dan satu galon oli bekas sudah cukup untuk mencemari sejuta galon air dan membentuk lapisan minyak seluas 3,7 hektar.

Secara detail skema dihasilkannya limbah dari sektor rumah tangga dapat digambarkan seperti pada Gambar 3, sedangkan contoh produk dari rumah tangga yang berpotensi menjadi limbah B3 dapat dilihat pada Tabel 2.

Komposisi sampah B3 di dalam sampah domestik di wilayah DKI Jakarta dapat dilihat seperti pada Lampiran Tabel 3.

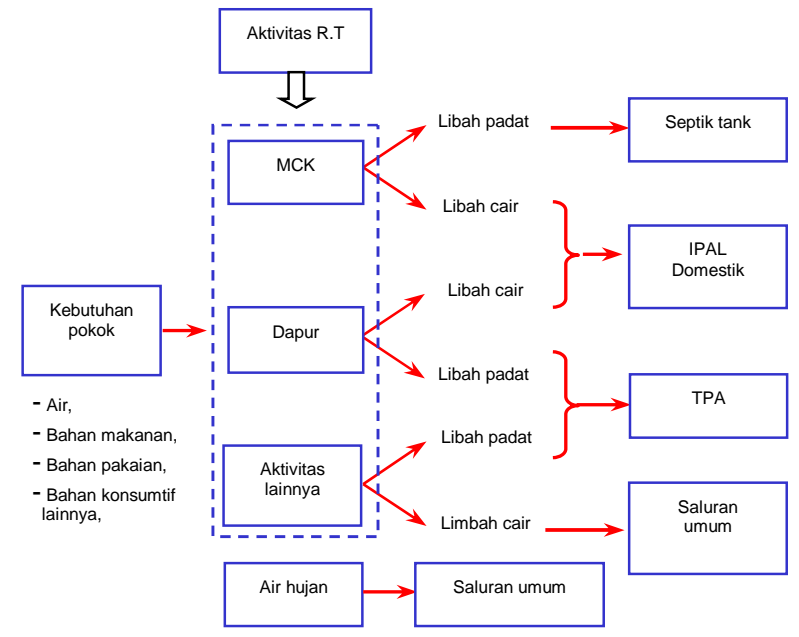

Gambar 3 : Skema sumber limbah B3 dari rumah tangga.

Tabel 2: Contoh produk rumah tangga yang berpotensi menjadi limbah B3

\begin{tabular}{|c|c|c|}
\hline No & Sumber & $\begin{array}{l}\text { Produk Yang Berpotensi Menjadi Limbah } \\
\text { B3 }\end{array}$ \\
\hline 1 & Dari Dapur & $\begin{array}{l}\text { Pembersih Lantai, Kompos Gas, } \\
\text { Pembersih Kaca, Plastik, Racun Tikus, } \\
\text { Bubuk Pembersih, Pembuka Sumbat, } \\
\text { Saluran Air Kotor. }\end{array}$ \\
\hline 2 & $\begin{array}{l}\text { Dari Tempat } \\
\text { Cuci }\end{array}$ & $\begin{array}{l}\text { Pemutih, Deterjen, Pembersih } \begin{array}{c}\text { Lantai, } \\
\text { Bahan Pencelup, Semir }\end{array} \text { Sepatu, } \\
\text { Pembersih Karpet, Pembuka Sumbat, } \\
\text { Saluran Air Kotor. }\end{array}$ \\
\hline 3 & $\begin{array}{l}\text { Dari Kamar } \\
\text { Mandi }\end{array}$ & $\begin{array}{l}\text { Aerosol, Desinfektan, Pembuka Sumbat, } \\
\text { Saluran Air Kotor, Pembersih Lantai dan } \\
\text { Kaca, Hair Spray, Pewarna Rambut, } \\
\text { Pembersih Toilet, Kamper, Medicated } \\
\text { Shampoo. }\end{array}$ \\
\hline 4 & $\begin{array}{l}\text { Dari Kamar } \\
\text { Tidur }\end{array}$ & $\begin{array}{l}\text { Kamper, Pembersih Karpet, Pembersih } \\
\text { Mebel, Pembersih Lantai, Pembersih } \\
\text { Kaca, Semir Sepatu, Obat Anti Nyamuk, } \\
\text { Batere, Pembersih Lantai, Aerosol, Cat } \\
\text { Kuku dan Pembersih. }\end{array}$ \\
\hline 5 & $\begin{array}{l}\text { Dari Garasi } \\
\text { dan Gudang }\end{array}$ & $\begin{array}{l}\text { Oli, Aki Mobil, Minyak Rem, Car Wax, } \\
\text { Pembersih Karburator, Cat dan Thinner, } \\
\text { Lem, Pembunuh Tikus, Genteng Asbes. }\end{array}$ \\
\hline 6 & $\begin{array}{l}\text { Dari Ruang } \\
\text { Tamu }\end{array}$ & $\begin{array}{l}\text { Pengharum Ruangan, Pembersih Karpet, } \\
\text { Pembersih Mebel, Pembersih Kaca. }\end{array}$ \\
\hline 7 & Dari Taman & Pupuk, Insektisida. \\
\hline 8 & $\begin{array}{l}\text { Dari Ruang } \\
\text { Makan }\end{array}$ & Obat Kadaluarsa. \\
\hline
\end{tabular}

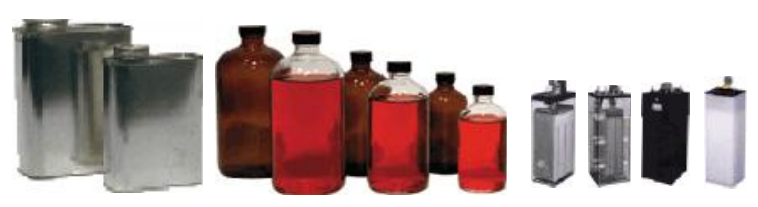

Gambar 4 : Kaleng, botol dan aki bekas merupakan contoh limbah B3 dari rumah tangga. 


\subsection{Limbah B3 dari sektor rumah sakit}

Rumah Sakit adalah sarana kesehatan yang menyelenggarakan kegiatan pelayanan kesehatan serta dapat dimanfaatkan untuk pendidikan tenaga kesehatan dan penelitian. Pelayanan kesehatan yang dilaksanakan di Rumah sakit meliputi pelayanan rawat jalan, rawat-inap, pelayanan gawat darurat, pelayanan medik, pelayanan penunjang medik dan pelayanan non medik.

Adanya berbagai sarana pelayanan kesehatan tersebut, akan menghasilkan limbah baik cair maupun padat. Limbah padat yang ada dapat dikelompokkan menjadi dua , yaitu limbah medis dan limbah non medis. Limbah medis adalah limbah yang dihasilkan langsung dari kegiatan medis. Limbah ini tergolong dalam kategori limbah bahan berbahaya dan beracun (B-3) sehingga berpotensi membahayakan komunitas rumah sakit. Jika pembuangan limbah medis tidak memenuhi syarat akan menimbulkan bahaya terhadap masyarakat di sekitar lokasi pembuangan. Limbah non-medis adalah limbah domestik yang dihasilkan di RS tersebut. Sebagian besar limbah ini merupakan limbah organik dan bukan merupakan limbah B-3, sehingga pengelolaannya dapat dilakukan bersama-sama dengan sampah kota yang ada.

Beberapa kegiatan yang ada di rumah sakit akan menghasilkan limbah dengan berbagai karakteristik yang berlainan. Pada Tabel 4 menunjukkan berbagai kegiatan rumah sakit yang menghasilkan limbah.

Berdasarkan potensi bahaya yang dapat ditimbulkannya, oleh Departemen Kesehatan RI limbah medis telah digolongkan sebagai berikut:

(a). Limbah benda tajam, yaitu obyek atau alat yang memiliki sudut tajam, sisi, ujung atau bagian yang menonjol yang dapat memotong atau menusuk kulit, seperti jarum hipodermik, perlengkapan intravena, pipet pasteur, pecahan gelas dan pisau bedah.

(b). Limbah infeksius, yaitu limbah yang berkaitan dengan pasien yang memerlukan isolasi penyakit menular dan limbah laboratorium yang berkaitan dengan pemeriksaan mikrobiologi dari poliklinik dan ruang perawatan/isolasi penyakit menular.

(c). Limbah jaringan tubuh, yang meliputi organ, anggota badan, darah dan cairan tubuh. Biasanya dihasilkan pada saat pembedahan atau autopsi.

(d). Limbah sitotoksik, yaitu bahan yang terkontaminasi oleh obat sitotoksik selama peracikan, pengangkutan atau tindakan terapi sitotoksik.

(e). Limbah farmasi, yaitu terdiri dari obatobatan kedaluwarsa, obat yang terbuang karena karena batch yang tidak memenuhi spesifikasi atau kemasan yang terkontaminasi, obat yang tidak diperlukan lagi atau limbah dari proses produksi obat.

(f). Limbah kimia, yaitu limbah yang dihasilkan dari penggunaan bahan kimia dalam tindakan medis, veterenary, laboratorium, proses sterilisasi atau riset. Dalam hal ini dibedakan dengan buangan kimia yang termasuk dalam limbah farmasi dan sitotoksik.

(g). Limbah radioaktif, yaitu bahan yang terkontaminasi dengan radio isotop yang berasal dari penggunaan medis atau riset radionuklida.

Tabel 4 : Jenis kegiaan rumah sakit yang berpotensi menghasilkan limbah

\begin{tabular}{|c|c|c|}
\hline No & Unit/kegiatan & Jenis limbah \\
\hline 1 & $\begin{array}{l}\text { Kantor } \\
\text { /administrasi }\end{array}$ & Kertas \\
\hline 2 & $\begin{array}{l}\text { Unit obstetric } \\
\text { dan ruang } \\
\text { perawatan } \\
\text { obstetric }\end{array}$ & $\begin{array}{l}\text { Dressing, sponge, placenta, } \\
\text { ampul, termasuk kapsul perak } \\
\text { nitrat, Jarum syrynge, masker } \\
\text { disposable, disposable drapes, } \\
\text { sanitary nnnnnapkin nx napkin, } \\
\text { blood blood lancet disposeble } \\
\text { diaper dan underpard, sarsarung } \\
\text { sarung tangan disposeble. }\end{array}$ \\
\hline 3 & $\begin{array}{l}\text { Unit } \\
\text { emergency } \\
\text { dan bedah } \\
\text { termasuk } \\
\text { ruang } \\
\text { perawata. }\end{array}$ & $\begin{array}{l}\text { Dressing,sponge jaringan } \\
\text { tubuh,termasuk amputasi, } \\
\text { ampul bekas,masker } \\
\text { disposeble, jarum dan syringe } \\
\text { drapes cabs. Disposeble blood } \\
\text { lancet disposeblekantong } \\
\text { emisis, levin tubes catheter, } \\
\text { drainase set, kantong } \\
\text { colosiomy, underpads, sarung }\end{array}$ \\
\hline 4 & $\begin{array}{l}\text { Unit } \\
\text { laboratorium, } \\
\text { ruang mayat, } \\
\text { pathoologi } \\
\text { dan autopsi }\end{array}$ & $\begin{array}{l}\text { Gelas terkontaminasi termasuk } \\
\text { pipet petri dish, wadah } \\
\text { specimen, slide specimen, } \\
\text { jaringan tubuh, organ, tulang. }\end{array}$ \\
\hline 5 & Unit isolasi & $\begin{array}{l}\text { Bahan-bahan kertas yang } \\
\text { mengandung buangan nasal } \\
\text { dan sputum, dressing, dan } \\
\text { bandages, masker disposable, } \\
\text { sisa makanan perlengkapan } \\
\text { makan. }\end{array}$ \\
\hline 6 & $\begin{array}{l}\text { Unit } \\
\text { perawatan }\end{array}$ & $\begin{array}{l}\text { Ampul, jarum disposable, dan } \\
\text { syringe kertas dan lain-lain. }\end{array}$ \\
\hline 7 & $\begin{array}{l}\text { Unit } \\
\text { pelayanan }\end{array}$ & $\begin{array}{l}\text { Karton kertas bungkus, kaleng, } \\
\text { botol, sampah dari ruang umum } \\
\text { dan pasien, sisa makanan, } \\
\text { buangan. }\end{array}$ \\
\hline 8 & Unit gizi/dapur & $\begin{array}{l}\text { Sisa pembungkus, sisa } \\
\text { makanan/bahan makan, sayur } \\
\text { dan lain-lain. }\end{array}$ \\
\hline 9 & Halaman & $\begin{array}{l}\text { Sisa pembungkus daun ranting, } \\
\text { debu. }\end{array}$ \\
\hline
\end{tabular}

Sumber : Oviatt V.R.: Status report -disposal of solid waste, Hospital, 42: $73-76,1968$.

Foto $10 \mathrm{~s} / \mathrm{d} 12$ menunjukkan berbagai contoh limbah rumah sakit. 


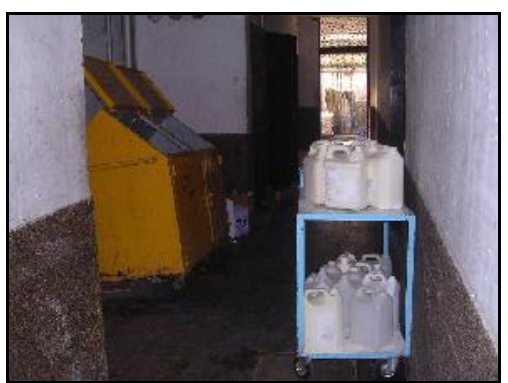

Foto 10 : Cairan pembersih.

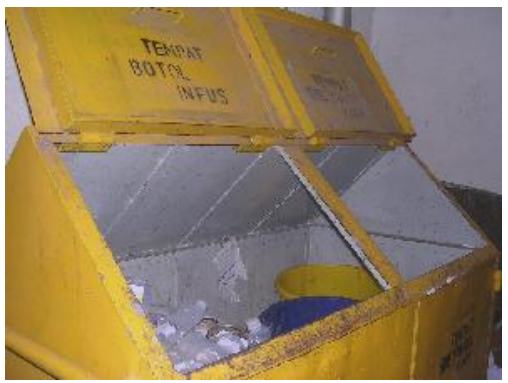

Foto 11 : Jarum suntik, botol infus, kapas bekas dan botol bekas.

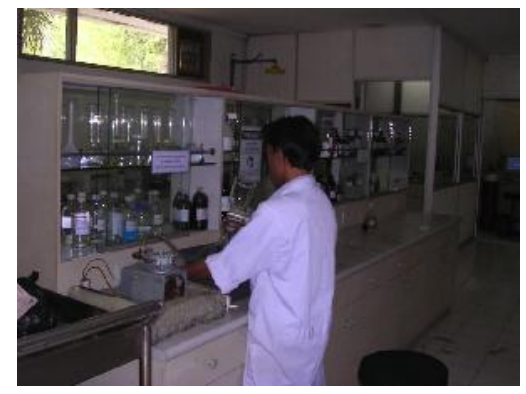

Foto 12 : Laboratorium Rumah Sakit.

Selain limbah medis, R.S juga menghasilkan non-medis. Jenis limbah non medis tersebut antara lain, limbah cair dari kegiatan loundry, limbah domestik cair dan sampah padat.

Data jumlah Rumah Sakit dan Puskesmas di wilayah DKI Jakarta tahun 2003 di sajikan pada Tabel 5.Potensi timbulan limbah B3 di tiap propinsi secara nasional dapat dilihat pada Lampiran Tabel 6, sedangkan potensi penghasil limbah B3 secara nasional pada tahun 1990 2003 dapat dilihat pada Lampiran Tabel 7.

\subsection{Yang Harus Dilakukan Dalam Menghadapai Limbah B3}

Kurangnya pengetahuan di masyarakat mengenai limbah B3 menyebabkan sulitnya menangani limbah B3 ditambah lagi tidak adanya fasilitas yang dapat dimanfaatkan masyarakat umum untuk mengelola limbah B3 secara baik. Namun demikian penanganan limbah B3 harus diupayakan semaksimal mungkin untuk menghindari bahaya yang lebih besar. Untuk itu diperlukan petunjuk-petunjuk praktis penggunaan bahan berbahaya dan upaya minimalisasinya serta petunjuk praktis penanganan limbah B3.

Tabel 5. : Daftar Rumah Sakit di Jakarta Pusat tahun 2003

\begin{tabular}{|c|c|c|c|}
\hline LOKASI & Jml RS & Jml TT & $\begin{array}{c}\text { Jmh } \\
\text { Puskesmas }\end{array}$ \\
\hline $\begin{array}{l}\text { Jakarta } \\
\text { Pusat }\end{array}$ & 28 & 6.054 & 40 \\
\hline $\begin{array}{l}\text { Jakarta } \\
\text { Utara }\end{array}$ & 12 & 1.189 & 48 \\
\hline Jakarta Barat & 15 & 2.715 & 74 \\
\hline $\begin{array}{l}\text { Jakarta } \\
\text { Selatan }\end{array}$ & 27 & 3.343 & 78 \\
\hline $\begin{array}{l}\text { Jakarta } \\
\text { Timur }\end{array}$ & 25 & 3.673 & 87 \\
\hline Kep. Seribu & - & - & 6 \\
\hline Total & 107 & 16.974 & 333 \\
\hline
\end{tabular}

Sumber : Dinas Kesehatan DKI

\subsubsection{Petunjuk Praktis Penanganan Limbah B3 Dari Sektor Rumah Tangga}

Pengelolaan limbah B3 dari sektor rumah tangga masih banyak menghadapi kendala antara lain:

- Belum optimalnya sistem pengelolaan limbah B3 dibentuk oleh pemerintah.

- Belum adanya petugas khusus yang menangani limbah B3 di lapangan dari instansi yang berwenang selaku penanggung jawab dalam pengelolaan limbah B3.

- Tidak adanya fasilitas yang memadai untuk mengelola limbah B3 di tingkat masyarakat, maupun instansi yang berwenang.

- Minimnya tingkat pengetahuan masyarakat tentang limbah B3.

- Tidak ada investor yang mau menanamkan modalnya untuk mengelola limbah B3 dari sektor domestik.

Adanya berbagai kendala tersebut, menyebabkan limbah B3 dari sektor rumah tangga tidak termonitor keberadaannya dan karena semua limbah domestik dikirim ke TPA maka dapat dipastikan limbah B3 ini juga tercampur di dalam TPA. Untuk mengantisipasi hal-hal yang tidak diharapkan, maka sudah selayaknya kita harus ikut untuk ambil bagian dalam menangani permasalahan ini.

Ada tiga aspek utama yang dapat dilakukan dalam melakukan pengelolaan limbah 
B3, yaitu : minimisasi limbah dari sumbernya, pemilahan limbah B3 dari limbah non-B3 dari sumbernya, dan pengolahan limbah B3.

Ada beberapa hal yang dapat kita lakukan untuk meminimisasi limbah B3, yaitu :

a) Ganti bahan yang menghasilkan limbah B3 dengan bahan lain yang tidak berbahaya.

b) Gunakan bahan sehemat mungkin sesuai petunjuk pemakaian dan sampai habis.

c) Bila produk masih ada namun kita tidak ingin menghabiskannya, berikan kepada orang lain yang membutuhkannya.

d) Daur Ulang kemasan atau produk bekasnya. Yang mengandung logam berat, tidak boleh dibakar atau dibuang sembarangan.

e) Supaya aman, gunakan produk dalam ruangan yang berventilasi baik dan jangan menghirup terlalu lama.

f) Perhatikan betul petunjuk pemakaiannya.

g) Simpan ditempat yang tidak mudah dijangkau anak-anak, dan tidak langsung kena sinar matahari dan hujan.

Ada beberapa contoh produk pengganti yang dapat gunakan antara lain :

a) Semprotan aerosol diganti dengan semprotan non aerosol.

b) Untuk membersihkan saluran air kotor, sekali seminggu digelontor dengan air mendidih atau campuran segenggam baking soda dan setengah cangkir cuka.

c) Untuk mengkilapkan mebel, gunakan campuran minyak lemon dan minyak nabati.

d) Untuk cat pilih cat lateks atau cat tembok yang dapat dibersihkan tanpa thinner.

Pemilahan limbah B3 dan non-B3 akan memudahkan pengambilan barang-barang yang masih dapat didaur ulang sehingga akan meminikan jumlah limbah B3 yang harus diolah.

Teknologi pengolahan limbah B3 disesuaiakan dengan karakteristik dari limbahnya.

\subsubsection{Petunjuk Praktis Penanganan Limbah B3 Dari Sektor Industri/Perusahaan}

Untuk menghindari hal-hal yang tidak diinginkan seperti keracunan, kebakaran, ledakan, radiasi dll, maka para penghasil limbah B3 dituntut untuk mengambil tindakan-tindakan preventif pencegahannya. Langkah pertama yang harus ditempuh para penghasil limbah adalah melakukan identifikasi karakteristik dari limbahnya. Secara detail langkah-langkah yang harus dilakukan jika kita menghasilkan/ menangani limbah adalah seperti yang tertera pada diagram alir Gambar 5 .

Identifikasi limbah adalah langkah untuk menentukan karakteristik / sifat-sifat dari limbah bersangkutan. Identifikasi dilakukan dengan analisis fisika, kimia dan biologi dari limbah, sehingga dari hasil analisis tersebut dapat diketahui sifat-sifat yang ada di dalam limbah. Hal ini bertujuan untuk mengetahui apakah limbah dapat menimbulkan bahaya (masuk dalam kategori limbah B3) atau tidak. Jika limbah masuk dalam kategori limbah B3, maka perlu diambil langkah-langkah preventif agar tidak terjadi hal-hal yang tidak diinginkan (kecelakaan kerja).

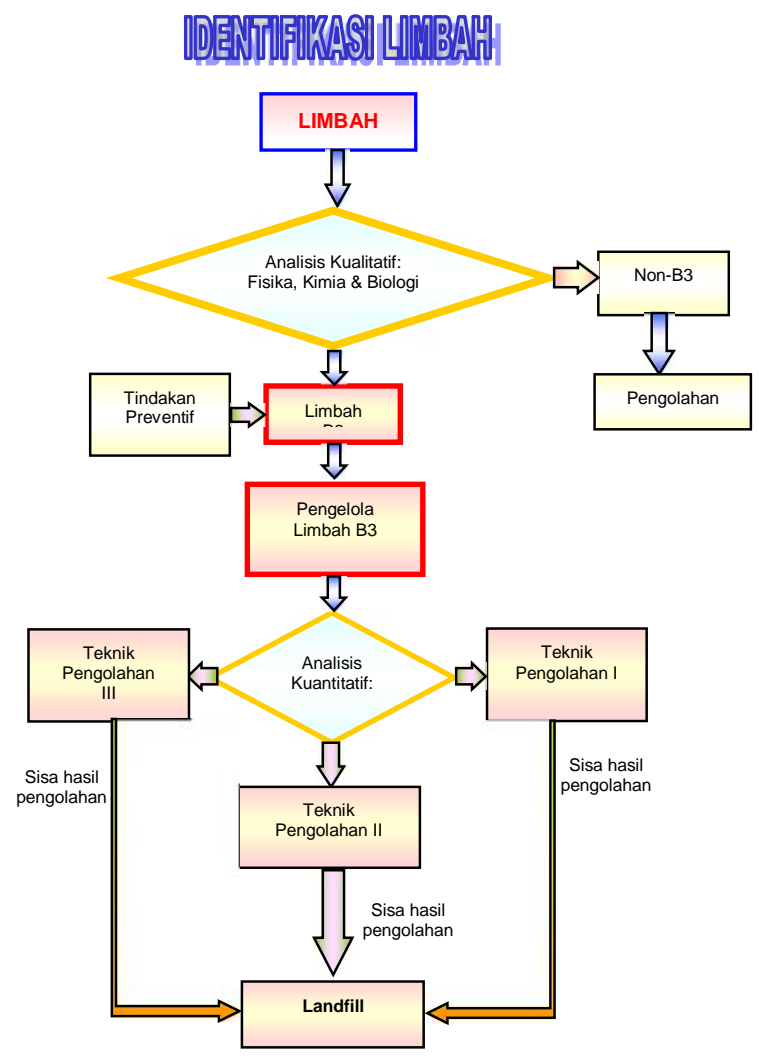

Gambar 5: Diagram alir langkah-langkah pengambilan keputusan dalam menangani limbah.

Limbah yang masuk dalam kategori limbah B3 harus dilakukan pengelolaan secara khusus yang biasanya diserahkan ke pihak pengelola limbah B3. Pihak pengelolan limbah B3 akan melakukan analisis kuantitatif untuk menentukan teknik pengolahan limbah yang tepat agar limbah dapat distabilkan atau dihilangkan dari sifat-sifat bahayanya. Sisa dari pengolahan tersebut harus dilandfill di lokasi penimbunan limbah B3 yang mempunyai disaint 
khusus sehingga tidak akan menimbulkan bahaya bagi lingkungan sekitarnya.

Saat ini di Indonesia ada satu lokasi landfill limbah B3 yang direkomendasikan, yaitu PPLI di Cileungsi Bogor. Sedangkan pengelola limbah B3 selain PPLI adalah satu perusahaan pengolah limbah B3 cair yang berlokasi di Cikarang, Bekasi. Kedua perusahaan tersebut saat ini mempunyai teknologi pengolahan limbah yang telah direkomendasikan oleh KLH.

\section{STRATEGI DAN PRIORITAS PENGELOLAAN}

\subsection{Strategi Pengelolaan}

\begin{abstract}
Setelah terkumpulkannya data-data jumlah, sebaran dan permasalahanpermasalahan tentang limbah B3 dan beberapa faktor yang mempengaruhi dalam pengelolaan limbah B3 seperti tersebut di atas, maka perlu disusun suatu strategi dalam pengelolaan limbah B3. Ada beberapa program/penanganan yang diusulkan untuk dapat melakukan pengelolaan limbah B3 di DKI yang terbagi dalam program jangka pendek, program jangka menengah dan program jangka panjang, yaitu sebagai berikut:
\end{abstract}

\subsubsection{Strategi Jangka Pendek}

$>$ Inventarisasi dan pemetaan sumber-sumber penghasil limbah B3 dari sektor kegiatan kecil dan rumah tangga di wilayah DKI.

> Evaluasi sistem pengelolaan limbah B3 (khususnya dari sumber kegiatan kecil dan rumah tangga) di wilayah DKI.

$>$ Pembentukan unit pelaksana teknis pengelolaan limbah B3 yang lebih professional.

> Program penyuluhan/ kampenye penanggulangan limbah B3.

> Program minimalisasi limbah B3 dari sumbernya.

> Program pemilahan limbah B3 dari sampah domestik.

> Studi kelayakan usaha pengelolaan limbah B3.

> Menjalin kerjasama dengan para pihak yang bergerak dalam pengelolaan limbah B3 (Pusat Pengolahan Limbah B3, Pengusaha Pengumpulan limbah B3, Pengusaha Pemanfaat Limbah B3 dll).

> Memberikan pembinaan teknis kepada para pemilik lapak yang mengumpulkan limbah yang terkontaminasi dengan limbah B3.

\subsubsection{Strategi Jangka Menengah}

- Studi kelayakan lokasi (pencarian lokasi) yang tepat untuk membangun sarana penimbunan dan pengolahan limbah B3.

- Pembangunan sarana penimbunan dan pengolahan limbah B3.

- Penyusunan Perda tentang usaha pengelolaan limbah B3.

- Penyusunan Perda tentang pengelolaan limbah B3 oleh penghasil limbah B3.

\subsubsection{Strategi Jangka Panjang}

- Pengadaan fasilitas pengumpulan limbah B3 (kendaraan operasional) pengumpulan limbah B3 dari sumber rumah tangga dan usaha kecil.

- Pengadaan fasilitas pengumpulan limbah B3 di tingkat rumah tangga atau RT.

- Operasioanal system pengumpulan limbah B3 dari sumbernya.

- Pembentukan BUMD dalam bidang pengelolaan limbah B3.

\subsection{Prioritas Pengelolaan Limbah B3}

Dari sepuluh sumber penghasil limbah B3 yang dikawatirkan oleh Dinas Kebersihan DKI belum mampu mengelola limbah B3 nya tersebut tidak semuanya memiliki kemampuan yang sama. Baik kemampuan finansial, teknologi, maupun SDM-nya masing-masing sangatlah berbeda. Adanya perbedaan tersebut membuat Pemda harus membuat prioritas penanganannya. Penentuan prioritas penanganan harus mempertimbangkan dari berbagai sector, antara lain sector finansial, sector SDM, ketersediaan teknologi, dan juga tingkat bahaya limbah B3 yang dihasilkannya.

Berikut adalah urutan prioritas penghasil limbah B3 yang akan segera dilakukan pengelolaannya:

i. rumah sakit tipe $C$ dan $D$,

ii. pengumpul minyak pelumas bekas,

iii. laboratorium,

iv. pengelolaan pestisida kadaluarsa,

v. cuci cetak film,

vi.percetakan,

vii. penyamakan kulit,

viii. bengkel-bengkel,

ix.binatu (Laundry \& Dry Cleaning),

$x$. rumah tangga. 


\section{KESIMPULAN DAN SARAN}

\subsection{Kesimpulan}

- Sampah domestik di wilayah DKI Jakarta mengandung sampah B3 yang membahayakan.

- Kandungan sampah B3 dari sektor domestik tersebut dapat mencapai 1,07\%.

- Sebagian dari sampah B3 dari sektor domestik telah diambil oleh pemulung $(0,47 \%)$.

- Sisa sampah B3 yang belum diambil oleh pemulung $(0,6 \%)$ sampai saat ini belum dikelola.

- Pemanfaatan dan pengelolaan sampah B3 yang diambil oleh pemulung juga tidak diketahui.

- Tingkat pengetahuan masyarakat tentang sampah B3 masih sangat minim sekali.

- Meskipun Dinas Kebersihan telah memiliki Subdin Limbah B3 tetapi masyarakat belum mengetahui aktivitasnya di lapangan, sehingga masyarakat yang telah mempunyai pengetahuan tentang limbah B3 belum dapat memilahkan limbah B3 dari sampah domestiknya.

- Di lapangan juga tidak tersedia fasilitas khusus untuk mengelola limbah B3 yang dapat dimanfatkan oleh masyarakat.

- Tidak adanya petugas lapangan dan tidak tersedianya sarana pengelolaan limbah B3 di tingkat masyarakat umum menyebabkan limbah B3 yang dihasilkan oleh masyarakat tercampur dengan sampah domestik.

- Masuknya limbah B3 ke dalam TPA dapat menimbulkan pencemaran yang lebih berat.

- Sarana pengelolaan limbah B3 yang telah dibangun oleh Dinas Kebersihan masih sangat minim sekali dan perlu dilakukan standarisasi kualitas sesuai dengan peraturan perundangan yang ada.

- Sampai saat ini belum ada pihak swasta yang mau berinvestasi untuk mengelola limbah B3 dari sektor domestik.

\subsection{Saran}

Perlu dilakukan kajian khusus tentang limbah B3 yang bersumber dari sektor domestik di wilayah DKI, sehingga akan diketahui kondisi existing di lapangan.

- Setelah diketahui kondisi existing limbah B3, perlu disusun strategi khusus untuk mengelola limbah B3 dan penentuan prioritas pengelolaan yang berdasarkan data-data autentik dengan mempertimbangkan pula dampak dan jumlah limbah yang dihasilkan.
- Perlu dilakukan segera kampenye atau penyuluhan untuk memberikan pengetahuan tentang limbah B3 di tingkat masyarakat.

- Perlu segera dirintas penyediaan fasilitas di tingkat masyarakat umum untuk menampung limbah B3 dari sektor domestik.

- Upaya pencegahan masuknya limbah B3 ke TPA harus segera dilakukan.

\section{DAFTAR PUSTAKA}

1. Charles A. Wentz1989. Hazardous Waste Management. McGraw-Hill Book Company.

2. Mazac, Oldrich et.al. 1990. Geotechnical and Enviromental Geophysics: Determination of Hydraulic Conductivities by Surface Geoelectrical Methods, edited by Stanley H. Ward, V. II, Society of Exploration Geophysicist, Tulsa, Oklahoma.

3. Reynolds, J.M., 1997. An Introduction to Applied and Enviromental Geophysics, John Wiley \& Sons, New York.

4. Sekretariat Menteri Negara Sekretaris Negara. 1999. Peraturan Pemerintah Nomor 18 Tahun 1999 tentang Pengelolaan Limbah Berbahaya dan Beracun

5. Sekretariat Menteri Negara Sekretaris Negara. Peraturan Pemerintah Nomor 85 Tahun 1999 tentang Perubahan Atas Peraturan Pemerintah Nomor 18 Tahun 1999 tentang Pengelolaan Limbah Berbahaya dan Beracun

6. Sekretariat Menteri Negara Lingkungan Hidup. 1995. Keputusan Kepala BAPEDAL Nomor KEP01/BAPEDAL/09/1995 tentang Tata Cara dan Persyaratan Teknis Penyimpanan dan Pengumpulan Limbah Bahan Berbahaya dan Beracun

7. Sekretariat Menteri Negara Lingkungan Hidup. 1995. Keputusan Kepala BAPEDAL Nomor KEP03/BAPEDAL/09/1995 tentang Persyaratan Teknis Pengolahan Limbah Bahan Berbahaya dan Beracun

8. Sekretariat Menteri Negara Lingkungan Hidup. 1995. Keputusan Kepala BAPEDAL Nomor KEP04/BAPEDAL/09/1995 tentang Tata Cara Persyaratan Penimbunan Hasil Pengolahan, Persyaratan Lokasi Bekas Pengolahan, dan Lokasi Bekas Penimbunan Limbah Bahan Berbahaya dan Beracun

9. Sekretariat Menteri Negara Lingkungan Hidup. 1998. Keputusan Kepala 


\section{BAPEDAL Nomor KEP- 02/BAPEDAL/01/1998 tentang Tata Laksana Pengawasan Pengelolaan Limbah Bahan Berbahaya dan Beracun di Daerah.}

10. Setiyono, 2002, Sistem Pengelolaan Limbah B3 di Indonesia, Pusat Pengkajian dan Penerapan Teknologi Lingkungan (P3TL), Deputi TIEML, BPPT, Jakarta
11. Ward, S.H., 1990. Geotechnical and Enviromental Geophysics : Resistivity and Induced polarization Method, edited by Stanley H. Ward, V.I, Society of Exploration Geophysicist, Tulsa, Oklahoma.

\section{LAMPIRAN :}

Tabel 1: Jumlah Perusahaan /Industri Besar dan Sedang menurut Klasifikasi Industri DKI Jakarta Tahun $2000-2002$

\begin{tabular}{|c|c|c|c|c|c|c|}
\hline \multirow[b]{2}{*}{ Klasifikasi Industri } & \multicolumn{2}{|c|}{2000} & \multicolumn{2}{|c|}{2001} & \multicolumn{2}{|c|}{2002} \\
\hline & $\begin{array}{l}\text { Jumlah } \\
\text { Perusahaan }\end{array}$ & $\%$ pertumbuhan & $\begin{array}{l}\text { Jumlah } \\
\text { Perusahaan }\end{array}$ & 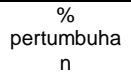 & $\begin{array}{l}\text { Jumlah } \\
\text { Perusahaan }\end{array}$ & $\begin{array}{c}\% \\
\text { pertumbuhan }\end{array}$ \\
\hline (1) & (8) & (9) & (10) & (11) & (12) & (13) \\
\hline $\begin{array}{l}\text { Makanan dan } \\
\text { Minuman }\end{array}$ & 205 & 6,22 & 220 & 7,32 & 214 & $-2,73$ \\
\hline $\begin{array}{l}\text { Tekstil, Pakaian Jadi } \\
\text { dan Kulit }\end{array}$ & 913 & 11,34 & 861 & $-5,70$ & 853 & $-0,93$ \\
\hline $\begin{array}{l}\text { Kayu, Bambu, Rotan, } \\
\text { Furnitur }\end{array}$ & 139 & 10,31 & 123 & $-11,51$ & 115 & - 0,07 \\
\hline $\begin{array}{l}\text { Kertas, Percetakan, } \\
\text { Penerbit, Reproduksi } \\
\text { Media Rekaman }\end{array}$ & 220 & 5,77 & 224 & 1,82 & 236 & 5,36 \\
\hline $\begin{array}{l}\text { Kimia dan barang- } \\
\text { barang dari bahan } \\
\text { kimia }\end{array}$ & 353 & 9,97 & 367 & 3,97 & 344 & $-6,27$ \\
\hline $\begin{array}{l}\text { Barang Galian bukan } \\
\text { Logam, Daur Ulang } \\
\text { Barang Bukan Logam }\end{array}$ & 41 & 7,89 & 33 & $-19,51$ & 32 & $-3,03$ \\
\hline Logam Dasar & 38 & 0,00 & 29 & $-23,68$ & 34 & 17,24 \\
\hline $\begin{array}{l}\text { Barang Dari Logam, } \\
\text { Mesin dan } \\
\text { Peralatannya, Daur } \\
\text { Ulang Barang Logam }\end{array}$ & 322 & $-1,23$ & 325 & 0,93 & 298 & $-8,31$ \\
\hline $\begin{array}{l}\text { Industri Pengolahan } \\
\text { Lainnya }\end{array}$ & 45 & $-13,46$ & 41 & $-8,89$ & 40 & $-2,44$ \\
\hline Jumlah & 2.276 & 7,26 & 2.223 & $-2,32$ & 2.166 & $-2,56$ \\
\hline
\end{tabular}

Sumber / Source : BPS Propinsi DKI Jakarta

Last Update : September 2003 
Tabel 3 : Komposisi Sampah B3 di Dalam Sampah Domestik di Wilayah DKI Jakarta

\begin{tabular}{|c|c|c|c|c|c|c|c|c|c|c|c|c|c|c|c|c|c|c|}
\hline \multirow{3}{*}{ No } & \multirow{3}{*}{ Komponen Sumber } & \multicolumn{2}{|c|}{ Pasar modern } & \multicolumn{2}{|c|}{ Industri } & \multicolumn{2}{|c|}{ Perkantoran } & \multicolumn{2}{|c|}{ Pasar } & \multicolumn{2}{|c|}{ Sekolah } & \multicolumn{6}{|c|}{ Rumah Tangga } & \multirow{3}{*}{$\begin{array}{c}\text { Rata-rata } \\
\% * 1\end{array}$} \\
\hline & & \multirow{2}{*}{$\begin{array}{l}\text { Berat } \\
(\mathrm{kg})\end{array}$} & \multirow[t]{2}{*}{$\%^{* 1}$} & \multirow{2}{*}{$\begin{array}{l}\text { Berat } \\
(\mathrm{kg})\end{array}$} & \multirow[t]{2}{*}{$\% *)$} & \multirow{2}{*}{$\begin{array}{l}\text { Berat } \\
(\mathrm{kg})\end{array}$} & \multirow[t]{2}{*}{$\% * 1$} & \multirow{2}{*}{$\begin{array}{l}\text { Berat } \\
(\mathrm{kg})\end{array}$} & \multirow[t]{2}{*}{$\% *)$} & \multirow{3}{*}{$\begin{array}{l}\text { Berat } \\
(\mathrm{kg})\end{array}$} & \multirow{2}{*}{$\% *)$} & \multicolumn{2}{|c|}{ Low } & \multicolumn{2}{|c|}{ Midle } & \multicolumn{2}{|c|}{ High } & \\
\hline & & & & & & & & & & & & $\begin{array}{l}\text { Berat } \\
(\mathrm{kg})\end{array}$ & $\% *)$ & $\begin{array}{l}\text { Berat } \\
(\mathrm{kg})\end{array}$ & $\% *)$ & $\begin{array}{l}\text { Berat } \\
(\mathrm{kg})\end{array}$ & $\% *)$ & \\
\hline & Total Berat Sampel & 133,9 & $100 \%$ & 84,63 & $100 \%$ & 76,36 & $100 \%$ & 145,36 & $100 \%$ & & $100 \%$ & 93,79 & $100 \%$ & 69,57 & $100 \%$ & 98,23 & $100 \%$ & \\
\hline 1 & Botol infus & & & & & & & & & & & & & & & - & 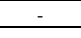 & - \\
\hline 2 & Jarum suntik & & & & & & & & & & & 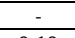 & 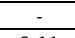 & - & 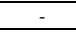 & - & - & \\
\hline 3 & Baterai & & & & & 0,5 & 0,65 & & & & & 0,10 & 0,11 & 0,15 & 0,22 & - & - & 0.12 \\
\hline 4 & Obat-obatan & & & 0,15 & 0,18 & 0,84 & $0,1,10$ & 0,18 & 0,12 & & & 0,40 & 0,42 & 0,11 & 0,16 & 0,39 & 0,40 & 0.30 \\
\hline 5 & Botol pembersih lantai* & & & & & $0,8^{*}$ & $1,05^{*}$ & & & $0,55^{*}$ & $0,62^{*}$ & $0,22^{*}$ & $0,23 *$ & $0,20^{*}$ & $0,28^{*}$ & $0,24^{*}$ & $0,24 *$ & $0.30^{*}$ \\
\hline 6 & Botol pembasmi serangga* & $0,2^{*}$ & $0,15^{*}$ & & & & & & & & & $0,21^{*}$ & $0,22^{*}$ & $0,19 *$ & $0,27^{*}$ & $0,27^{*}$ & $0,28^{*}$ & $0.12^{*}$ \\
\hline 8 & bohlam & & & & & 0,75 & 0,98 & & & 0,25 & 0,28 & 0,02 & 0,02 & 0,13 & 0,18 & - & - & 0.18 \\
\hline 9 & Oli bekas & & & & & & & & & & & & & & 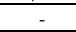 & 0,01 & 0,01 & \\
\hline \multirow{4}{*}{10} & kaleng cat bekas* & & & & & & & & & & & $0,03^{*}$ & $0,03^{*}$ & - & - & $0,25^{*}$ & $0,25^{*}$ & $0,04^{*}$ \\
\hline & Total sampah B3 & 0,2 & 0,15 & 0,15 & 0,18 & 2,89 & 3,78 & 0,18 & 0,12 & 0,8 & 0,90 & 0,98 & 1,03 & 0,78 & 1,11 & 1,22 & 1,25 & 1,07 \\
\hline & Yg diambil pemulung & 0,2 & 0,15 & 0 & 0 & 0,8 & 1,05 & 0 & 0 & 0,55 & 0,62 & 0,46 & 0,48 & 0,39 & 0,55 & 0,82 & 0,83 & 0,47 \\
\hline & Masuk ke TPA & 0 & 0 & 0,15 & 0,18 & 2,09 & 2,73 & 0,18 & 0,12 & 0,25 & 0,28 & 0,52 & 0,55 & 0,39 & 0,55 & 0,40 & 0,42 & 0,60 \\
\hline
\end{tabular}

Keterangan : * diambil oleh pemulung

Hasil survai sampah domestic di DKI Jakarta, Desember 2004. 
Tabel 6 : Potensi Timbulan Limbah B3 di Tiap Propinsi (dalam ton) Secara Nasional

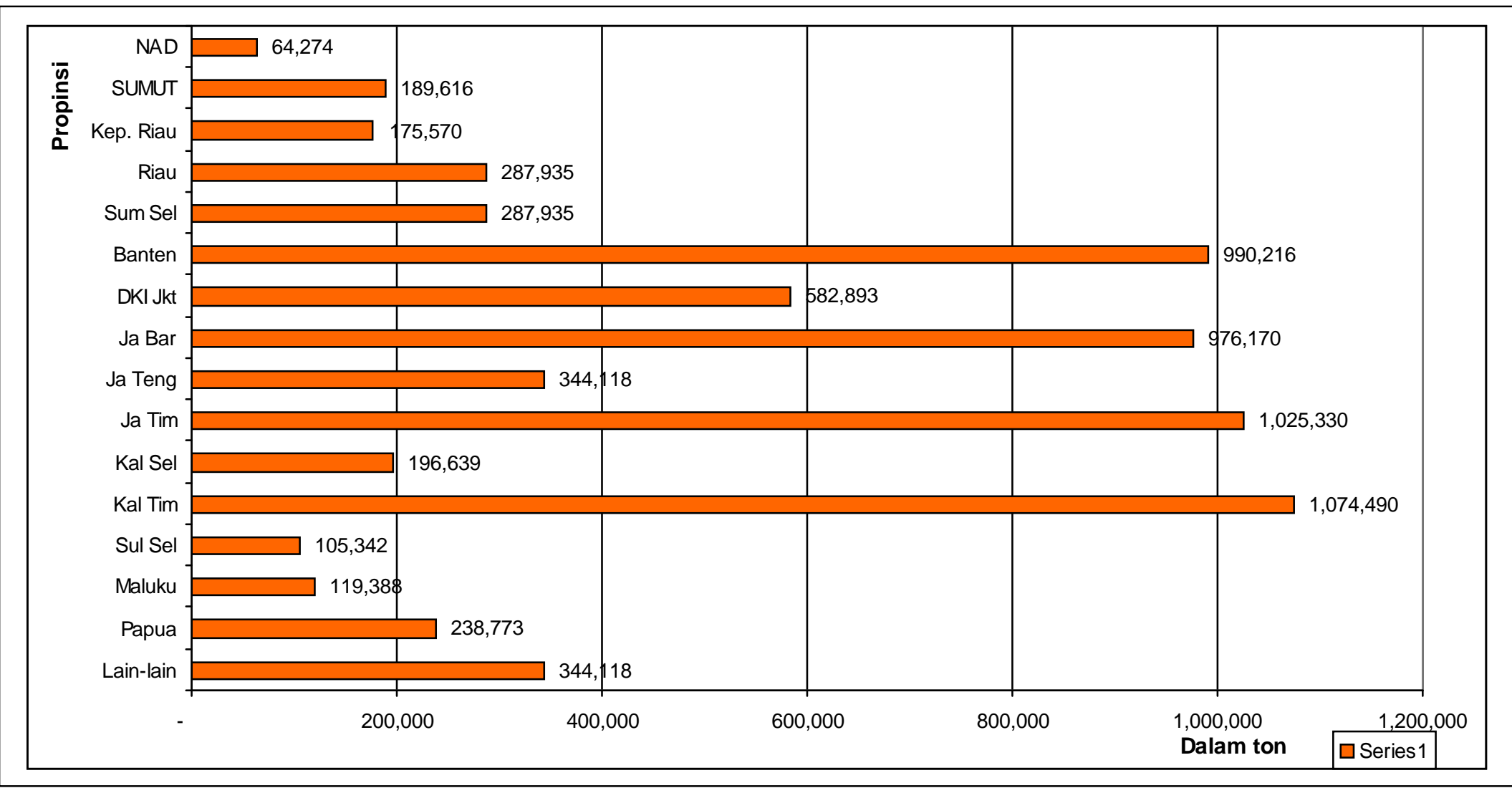

Sumber : PPLI, 2003, (Kompas, Selasa 26 April 2005) 
Tabel 7 : Potensi Timbulan Limbah B3 Tahun 1990 - 2003, (dalam ton)

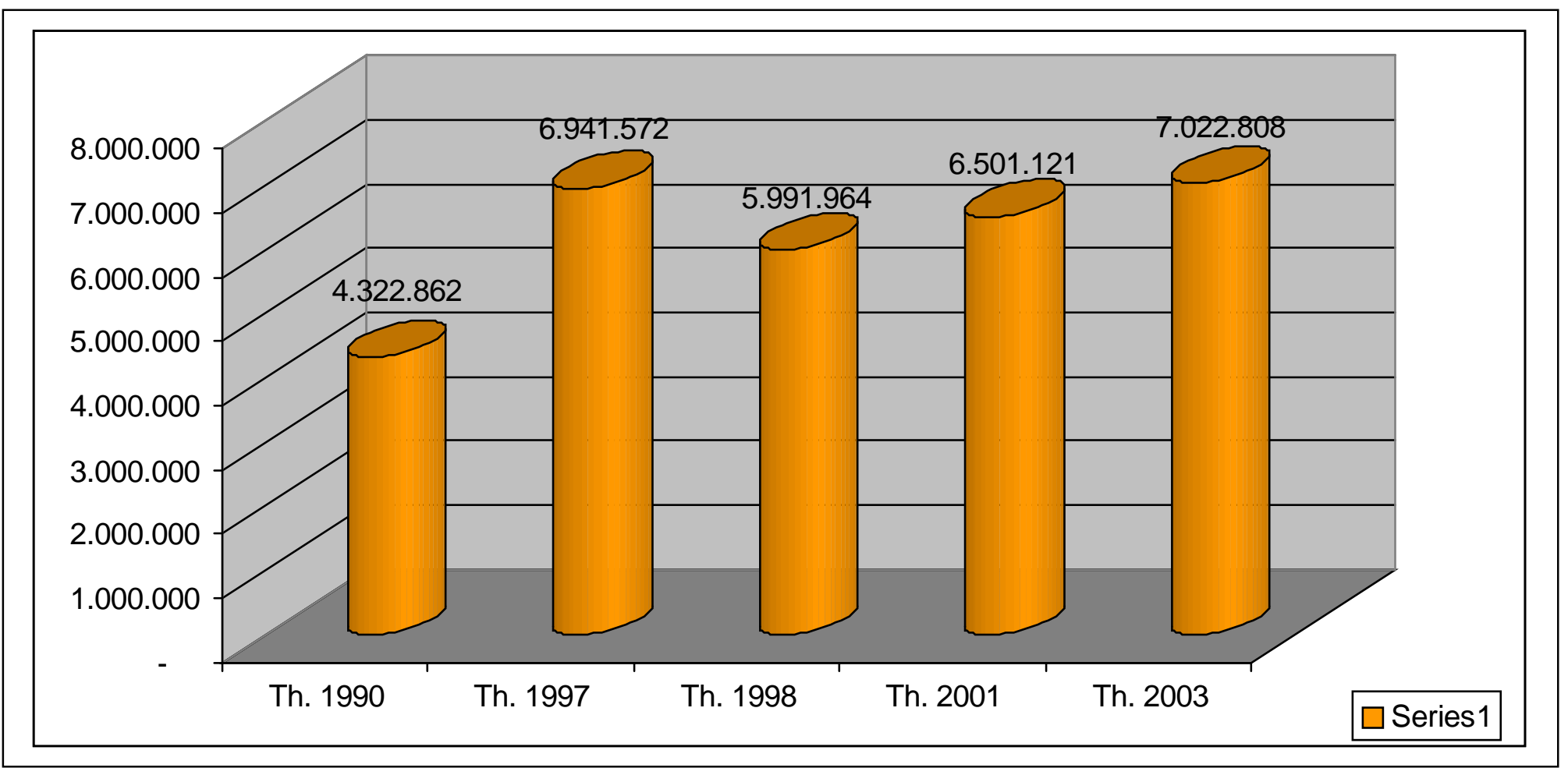

Sumber : PPLI, 2003, (Kompas, Selasa 26 April 2005) 